\title{
OCCURENCE OF MASTITIS IN DAIRY COWS SITUATED IN MARGINAL PARTS OF SLOVAKIA
}

\author{
Zigo, F. ${ }^{1}$, Vasil, M. ${ }^{1}$, Elečko, J. ${ }^{1}$, Farkašová, Z. ${ }^{1}$, Zigová, M. ${ }^{1,2}$ \\ ${ }^{1}$ Department of Animal Husbandry \\ University of Veterinary Medicine and Pharmacy, Komenského 73, 04181 Košice, \\ 2Department of Pharmacology \\ Faculty of Medicine, Pavol Jozef Šafarik University, 04011 Košice \\ Slovakia
}

frantisek.zigo@uvlf.sk

\section{ABSTRACT}

A relatively large part of the Slovak territory consists of the "marginal regions", which in terms of the economy of ruminants keeping can efficiently produce animal commodities only occasionally. The geographic, social and economic stability of these regions is strongly influenced by the rearing of ruminants and the associated market milk production. The aim of this study was to evaluate the prevalence and aetiological agents of mastitis in two herds of dairy cows situated in the marginal parts of Slovakia. In total, 530 of the Slovak spotted breed and Holstein cows were involved in the study. The diagnosis of mastitis was performed on the basis of the clinical examination of the udder, macroscopic evaluation of the milk, determination of somatic cell count (SCC), and the bacteriological examination of the milk. The prevalence of mastitis in the two herds of dairy cows ranged from $34.7 \%$ to $18.8 \%$, respectively. From the total of 2120 quarter milk samples, $36.3 \%$ were positive to the California mastitis test (CMT). Also, pathogenic microorganisms causing intramammary infection (IMI) were isolated from $25.6 \%$ of the samples, which accounted for most subclinical mastitis forms $(23.3 \%)$, with the SCC under 400000, mainly caused by coagulase-negative staphylococci (CoNS) and coliform bacteria E. coli and Enterobacter aerogenes. The clinical forms of mastitis accounted for $13.0 \%$ of all infected cows and were caused mainly by the bacteria: Streptococcus uberis, Streptococcus agalactiae, Staphylococcus aureus and coagulasenegative staphylococci.

Key words: dairy cows; mastitis; milk production; prevalence; Staphylococcus spp.

\section{INTRODUCTION}

Marginal regions cover relatively a large part of the Slovakia territory where the rearing of ruminants can efficiently produce animal commodities only occasionally. The geographic, social and economic stability of these regions are strongly influenced by the keeping of ruminants, particularly for marking milk production. The products from 
ruminants are unique, especially with regard to providing high quality nutrition to consumers. Many of the milk products and specialties can be included among the most important functional foods [16].

Mastitis is considered to be the most frequent and most costly production disease in dairy herds. Mastitis is characterized by an inflammation in one or more quarters of the udder and can be either clinical or subclinical. The decrease in milk production per cow due to the clinical and subclinical prevalence of mastitis is usually recognised as the main cause of economic losses due to the disease $[4,5,6]$.

The factors influencing the susceptibility of the mammary gland to infections are: the presence of bacteria at the teat end, level of efficacy of the protective characteristics of the teat canal, and defence mechanisms in the udder (Fig. 1) [11].

Contagious mastitis is caused by organisms transmitted from cow to cow; the primary reservoir of which is the cow itself. The predominant contagious pathogens involved in bovine mastitis are Staphylococcus spp. (S. aureus and S. epidermidis) [9, 12], Streptococcus spp. (Str. agalactiae, Str. dysgalactiae, Str. uberis and Str. bovis), coliforms (mainly E. coli and Klebsiella pneumoniae), and Enterobacter aerogenes $[14,15]$.

Clinical cases give rise to visible symptoms such as swelling, heat, pain in the affected quarters or clots and discolouration in the secretions. Losses caused by clinical mastitis include: reduced milk yield and quality, costs of veterinary care, discarded milk and shortening of productive life $[2,5]$. Cows with subclinical mastitis do not show a visible udder inflammation and can be diagnosed by somatic cell count (SCC) and by detection of the presence of the pathogens. The economic losses are more associated with sub-clinical mastitis which is $40 \%$ more prevalent than clinical mastitis. However, the cost of treatment of sub-clinical mastitis is much lower compared to that of clinical mastitis, accounting for 10-20 times higher [5].

The aim of this study was to evaluate, during early lactation, the prevalence and aetiological agents in two herds of dairy cows situated in the marginal parts of Slovakia.

\section{MATERIALS AND METHODS}

\section{Animals and milking}

The study was conducted in accordance with good veterinary practice. The practical part of the study was carried out on two farms situated in marginal parts of Slovakia (Orava and Zemplín). On the first farm (A) we investigated 150 Slovak spotted breed cows and on the second (B) 380 dairy cows of the Holstein breed, between second and fourth lactations. The dairy cows on both farms were kept in a free housing system with individual boxes with bedding and ad libitum access to water and a separate calving barn. The keeping of cows corresponded to standard animal hygiene rules. Both herds were fed a total mixed rations based on grass silage, maize silage and concentrates.

The cows from both herds were milked twice daily, herd $\mathrm{A}$ in a tandem parlour DeLaval 2x5 (Tumba, Sweden) and herd B in a parallel parlour Boumatic 2x12 Xpressway (Wisconsin, USA). The average milk yield was $6800 \mathrm{l}$ and 74001 per year in herds A and B, respectively. Blanket dry cow therapy (treatment of all quarters of all cows) was implemented in both herds.
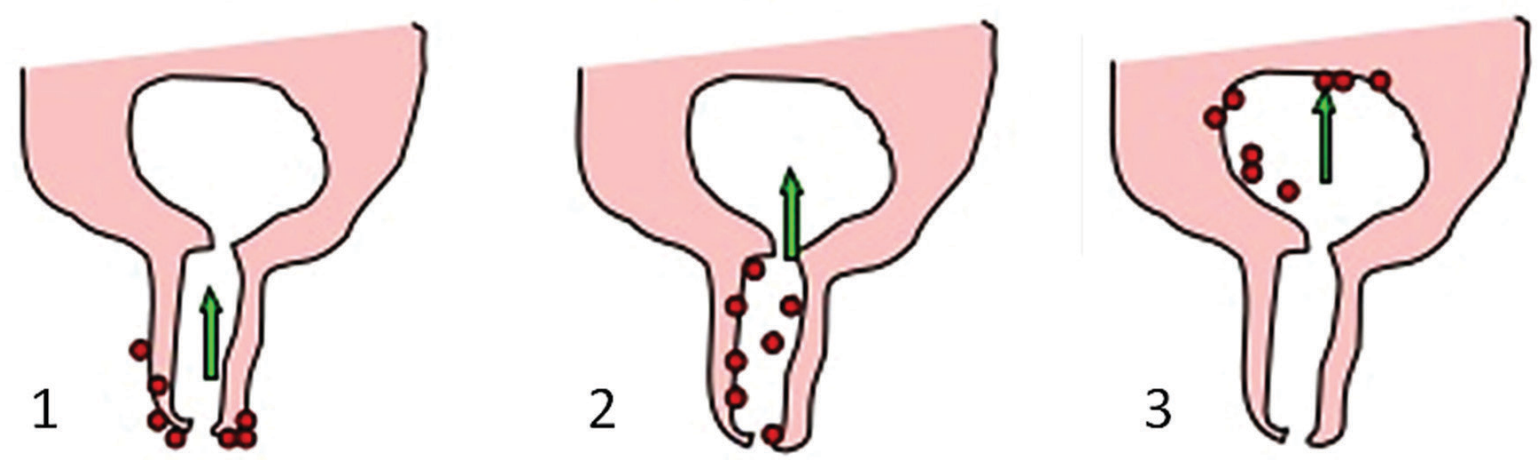

Fig. 1. Process of udder infection

1-Organisms invade the udder through teat canal; 2 - Migrate up the teat canal and colonize the secretory cells; 3 - Colonized organisms produce toxic substances harmful to the milk producing cells. Source: Jacks on and Cockcroft [3] 


\section{Collection of samples and laboratory analyses}

Double milk samples were collected aseptically from 2120 quarters (530 cows) during the first month of lactation. Eleven quarters were atrophic. The teats were cleaned and the first few streams were discarded. The teats were then dipped in a disinfectant and the teat ends were wiped with alcohol swabs and allowed to dry. Then $10 \mathrm{ml}$ of the milk was collected into sterile tubes. The samples were cooled and immediately transported to the laboratory. The SCC were analysed in a commercial laboratory using a MilkoScan FT2 (Foss Electric, Hillerod, Denmark).

The bacteriological examinations were performed according to commonly accepted rules [6]. Milk samples $(0.05 \mathrm{ml})$ were inoculated onto blood agar (Oxoid, UK) and cultivated at $37^{\circ} \mathrm{C}$ for $24 \mathrm{~h}$. Based on the colony morphology and Gram staining, Staphylococcus spp. bacteria were selected for the tube coagulase test (Staphylo PK, ImunaPharm, Slovakia). Suspected colonies of Staphylococcus spp., Streptococcus spp. and Enterobacteriacae spp. were isolated on blood agar, cultivated at $37^{\circ} \mathrm{C}$ for $24 \mathrm{~h}$ and identified biochemically using the STAPHY-test, STREPTOtest, or ENTERO-test, using software TNW Pro 7.0 (ErbaLachema, Czechia).

Individual forms of mastitis (subclinical, subacute and acute) based on clinical signs, CMT scores, SCC and bacteriological examination of milk samples were classified according to Vasil' et al. [14].

\section{Statistical analysis}

The statistical analysis was performed using Graph-Pad PRISM 6.0 (GraphPad Software Inc., USA). The differences in incidence of mastitis among the herds were statistically analysed using the Chi-square test. The level of significance was set at $\mathrm{P}<0.05$.

\section{RESULTS}

The results obtained by the California mastitis test (CMT) are presented in Table 1. The elevation of SCC to the level below $200000 \mathrm{ml}^{-1}$ was detected in $63.2 \%$ quarters on average. The average score $(>1)$ of CMT above $400000 \mathrm{ml}^{-1}$ was detected in $13.1 \%$ of the quarters. The prevalence of mastitis in the herds of dairy cows (A and B) was 34.7\% and $18.8 \%$, respectively.
The differences in the prevalence of subclinical and clinical forms of mastitis in the quarters between herds were statistically significant $(\mathrm{P}<0.05)$. The prevalence of subclinical mastitis in the quarters of the two herds $(\mathrm{A}, \mathrm{B})$ reached $35.3 \%$ and $20.6 \%$ and of clinical mastitis $14.6 \%$ and $6.8 \%$, respectively (Table 2 ).

The microorganisms isolated from mastitis in the herds are presented in Table 3. Pathogenic bacteria were isolated from $25.6 \%$ of the quarters with subclinical (14.2\%), and (12.4\%) with clinical mastitis. The aetiological agents of mastitis detected most frequently were CoNS, Str. agalactiae, Str. uberis, Enterococcus spp. and Bacillus spp. Staphylococci were the main aetiological agents of the intramammary infections (IMI) in the dairy herds and Staph. Aureus, Str. uberis and Str. agalactiae were the most frequent isolate from the clinical mastitis cases. In both herds, subclinical mastitis was caused mainly by Enterococcus spp., Enterobacter aerogenes and CoNS.

\section{DISCUSSION}

Bovine mastitis, as a major disease affecting dairy cattle worldwide, involves inflammation of the mammary gland [1]. Mastitis affects the milk quality and production of the cow and may spread to other cows in the herd. The severity of the inflammation can be classified as subclinical, clinical and chronic forms, and its degree is dependent on the nature of the causative pathogen and on the age, breed, immunological health and lactational status of the animal $[4,5]$.

Over 135 different organisms have been identified as the causative agents of bovine mastitis, including bacteria, viruses, mycoplasma, yeasts and algae [10]. In the present study, most of the mastitis cases were caused by CoNS and Streptococcus spp. Similar results were obtained in Poland by Malinowski et al. [6] and in Finland by Taponen et al. [12].

In our study the CoNS belong among the organisms most commonly isolated from milk samples of dairy cows with subclinical mastitis as in other studies [1, 8, 9].

In the Netherlands, the prevalence of CoNS among bacterial isolates from milk samples increased from $16.2 \%$ in 1999 to $42.2 \%$ in 2004 for subclinical mastitis, and from $7.3 \%$ to $14.1 \%$ for clinical mastitis [10].

In New Zealand, as in the UK, Str. uberis was the most common pathogen associated with clinical mastitis, but in 
Table 1. CMT scores related to average somatic cell counts 2120 (11 rejected) quarters

\begin{tabular}{cccc}
\hline CMT Score & SCC & \% of quarters & Interpretation* $^{*}$ \\
\hline $\mathrm{N}$ (Negative) & $0-200 \times 103$ & 63.2 & Healthy quarter \\
$\mathrm{T}($ Trace $)$ & $200-400 \times 103$ & 23.3 & Subclinical mastitis \\
1 & $400-1000 \times 103$ & 6.5 & Subclinical mastitis \\
2 & $1000-3000 \times 103$ & 4.6 & Serious mastitis Infection \\
3 & Over $3000 \times 103$ & 2.0 & Serious mastitis infection \\
\hline & $*-$ Jackson and Cockcroft [3]
\end{tabular}

Table 2. Prevalence of mastitis in the quarters of the herds

\begin{tabular}{|c|c|c|c|c|c|c|c|c|c|}
\hline \multirow{2}{*}{ Herd } & \multirow{2}{*}{$\begin{array}{l}\text { No. of examined } \\
\text { cows }\end{array}$} & \multirow{2}{*}{$\begin{array}{l}\text { No. of examined } \\
\text { quarters }\end{array}$} & \multicolumn{2}{|c|}{ Healthy quarters } & \multirow{2}{*}{$\begin{array}{l}\text { Rejected } \\
\text { quarters }\end{array}$} & \multicolumn{2}{|c|}{ Positive quarters } & \multicolumn{2}{|c|}{ Infected quarters } \\
\hline & & & $\mathrm{n}$ & $\%$ & & $\mathrm{n}$ & $\%$ & $\mathrm{n}$ & $\%$ \\
\hline A & 226 & 904 & 484 & 60.7 & 4 & 416 & 46.2 & 312 & $34.7 a$ \\
\hline B & 304 & 1216 & 862 & 66.2 & 7 & 354 & 29.3 & 227 & $18.8 \mathrm{~b}$ \\
\hline Total & 530 & 2120 & 1346 & 63.5 & 11 & 770 & 36.3 & 539 & 25.6 \\
\hline
\end{tabular}

a, b, c-values within the same column with different superscript letters differ significantly at $P<0.05$

Table 3. Microorganisms isolated from mastitis in the herds

\begin{tabular}{lccccccc}
\hline & & \multicolumn{2}{c}{ Subclinical } & \multicolumn{2}{c}{ Subacute } & \multicolumn{2}{c}{ Acute } \\
\cline { 3 - 7 } Isolated microorganisms & $\mathbf{n}$ & $\mathrm{A} \%$ & $\mathrm{~B} \%$ & $\mathrm{~A} \%$ & $\mathrm{~B} \%$ & $\mathrm{~A} \%$ & $\mathrm{~B} \%$ \\
\hline Staph. aureus & 41 & 9.8 & 4.9 & 31.7 & 17.1 & 22.0 & 14.6 \\
Str. uberis & 17 & 11.8 & - & 47.1 & - & 41.2 & - \\
Str. agalactiae & 62 & 14.5 & 6.5 & 38.7 & 11.3 & 22.6 & 6.5 \\
Streptococcus spp.* & 55 & 14.5 & 12.7 & 38.2 & 11.0 & - & 7.3 \\
CONS* & 141 & 35.5 & 23.4 & 19.9 & 12.1 & 5.0 & 4.3 \\
CPS* & 24 & 37.5 & 16.7 & 33.3 & 20.8 & - & - \\
E. coli & 36 & 44.4 & 25 & 19.4 & 11.1 & - & - \\
Enterococcus spp. & 75 & 62.7 & 37.3 & 12 & 20 & - & - \\
Bacillus spp. & 48 & 43.8 & 20.8 & 25 & 2.1 & - & 8.3 \\
Enterobacter aerogenes & 17 & 64.7 & 35.3 & 47.1 & - & - & 11.8 \\
Other* & 23 & 56.5 & 34.7 & 8.6 & - & - & - \\
Total & $\mathbf{5 3 9}$ & $\mathbf{3 5 . 3}$ & $\mathbf{2 0 . 6}$ & $\mathbf{2 6 . 3}$ & $\mathbf{1 1 . 5}$ & $\mathbf{6 . 9}$ & $\mathbf{4 . 1}$ \\
\hline
\end{tabular}

$\mathrm{n}$ - number of isolated bacteria; Other* - Proteus spp., Aerococuss spp.; CPS* - S. aureus, S. hyicus; Streptococcus spp.

* - Str. faecalis, Str. dysgalactiae, Str. Suis; CONS* - S. haemolyticus, S. chromogenes, S. xylosus, S. epidermidis, S. warneri 
contrast to the situation in the UK, E. coli mastitis was rarely observed [7]. In Norway, neither Str. uberis nor E. coli were commonly found. Rather, S. aureus and Str. dysgalactiae were the most common causes of clinical mastitis there [17]. The main pathogen associated with clinical mastitis in the Netherlands were CPS followed by Str. dysgalactiae, Str. uberis and E. coli [10]. IMI caused by Strep. dysgalactiae and mycoplasma were of major concern in the USA [3].

Coagulase-positive staphylococci (CPS) are permanently present in dairy herds. In our study, S. aureus and S. hyicus were isolated from $4.5 \%$ of the quarters with subacute and acute forms of mastitis. Similar results were obtained by Malinowski et al. [5], who found Staph. aureus in $5.1 \%$ of the cases of clinical and subclinical mastitis in the western part of Poland. This is in accordance with the data from other countries $[11,13]$.

\section{CONCLUSIONS}

The results of our study showed that the average prevalence of mastitis in two dairy herds (A and B) situated in marginal parts of Slovakia reached $14.1 \%$ and $30.1 \%$, respectively. The bacteria Staph. aureus, Str. agalactiae and Str. uberis were most frequently isolated from clinical mastitis. The CoNS were the pathogens most frequently isolated from subclinical mastitis cases. The pathogens Str. agalactiae and Staph. aureus played an important role in dairy herds in the marginal parts of Slovakia.

A successful mastitis control programme should focus on the management of dry and calving cows and heifers. A clean and comfortable environment, proper feeding and adequate supplementation of the diet with vitamins and trace elements are essential for maintaining good udder health.

\section{ACKNOWLEDGEMENT}

This study was supported by the project VEGA No. 1/0510/16.

\section{REFERENCES}

1. Bradley, A. J., Leach, K.A., Breen, J.E. et al., 2007: Survey of the incidence and aetiology of mastitis on dairy farms in England and Wales. Vet. Rec., 160, 253-257.

2. Fox, L. K., Kirk, J.H., Britten, A., 2005: Mycoplasma mastitis: a review of transmission and control. Jour. Vet. Med. Infect. Dis., 52, 153-60.

3. Jackson, P., Cockcroft, P., 2002: Clinical Examination of Farm Animals. Oxford, UK, Blackwell Science Ltd, Wiley-Blackwell, 154-166.

4. Malinowski, E., 2000: Mastitis prophylaxis and treatment during dry period - advantages and threats. Medycyna Weterynaryjna, 56, 759-763.

5. Malinowski, E., Gajewski, Z., 2009: Characteristics of cows mastitis caused by human foodborne pathogens. Życie Weterynaryjne, 84, 290-294.

6. Malinowski, E., Lassa, H., Kłossowska, A., Smulski, S., Markiewicz, H., Kaczmarowski, M., 2006: Etiological agents of dairy cows' mastitis in western part of Poland. Pol. J. Vet. Sci., 9, 191-194.

7. McDougall, S., 2003: Intramammary treatment of clinical mastitis of dairy cows with a combination of lincomycin and neomycin, or penicillin and dihydrostreptomycin. N.Z. Vet. J., $51,111-116$.

8. Østerås, O., Sølverød, L., Reksen, O., 2006: Milk culture results in a large Norwegian survey-effects of season, parity, days in milk, resistance, and clustering. J. Dairy Sci., 89, 1010-1023.

9. Pyörälä, S., Taponen, S., 2009: Coagulase-negative staphylococci-emerging mastitis pathogens. Vet. Microbiol., 134, $3-8$.

10. Sampimon, O.C., Vernooij, J.C., Mevius, D. J. et al., 2007: Sensitivity to various antibiotics of coagulase-negative staphylococci isolated from samples of milk from Dutch dairy cattle (In Dutch, English summary). Tijdschr. Diergeneeskd., 132, $200-204$

11. Sumathi, B. R., Veeragowda, B., Amitha, R. G., 2008: Prevalence and antibiogram profile of bacterial isolates from clinical bovine mastitis. Vet. World, 1, 237-238.

12. Taponen, S., Koort, J., Björkroth, J., Saloniemi, H., Pyörälä, S., 2007: Bovine intramammary infections caused by coagulase-negative staphylococci may persist throughout lactation according to amplified fragment length polymorphism based analysis. J. Dairy Sci., 90, 3301-3307. 
13. Tenhagen, B.A., Koster, G., Wallmann, J., Heuwieser, W., 2006: Prevalence of mastitis pathogens and their resistance against antimicrobial agents in dairy cows in Brandenburg, Germany. J. Dairy Sci., 89, 2542-2551.

14. Vasil, M., Elečko, J., Farkašová, Z., Bíreš, J., 2009: The reduction on the occurrence of mastitis in dairy herd using the innovation of housing conditions, sanitary of milk storage and applying the therapy of mastitis during the lactation. Folia Vet., 53, Suppl. II, 186-189.
15. Vasil', M., 2004: To know the etiology of mastitis in the herd (In Slovak, English summary). Slovenský Chov, 9, 20-22.

16. Vršková, M., Tančin, V., Kirchnerová, K., Sláma, P., 2015: Evaluation of daily milk production in Tsigai ewes by somatic cell count. Potravinárstvo, 9, 206-210.

17. Whist, A.C., Østerås, O., Sølverød, L., 2007: Streptococcus dysgalactiae isolates at calving and lactation performance within the same lactation. J. Dairy Sci., 90, 766-778.

Received September 12, 2017

Accepted October 16, 2017 